\title{
1 | Pompier-Pyromanocracy: Mbusa Nyamwisi and the DR Congo's inflammable post-settlement political order
}

\author{
Judith Verweijen
}

Published in: Themnér, A. (ed.) (2017). Warlord Democrats in Africa: Ex-Military Leaders and Electoral Politics, London: Zed Books, pp. 41-67.

\section{Introduction}

In April 2003, the belligerents of the Second Congo War (1998-2003) adopted a peace accord, signed in December 2002, that was bombastically dubbed the "Global and All-Inclusive Agreement". This inaugurated a transitional period that would last up to the organization of general elections in 2006. The accord paved the way for a double political and military power-sharing deal, implying that the breed of violent actors that had gained dominance during the war were officially entitled to a part of the "national cake". Positions in the politico-administrative apparatus were divided among the signatories of the peace deal, including the political representatives of former insurgent outfits, which were transformed into political parties. This form of power-sharing was mirrored in the military domain. New national armed forces were cobbled together from troops and officers of most of the ex-belligerent factions, leading to the creation of mixed units placed under an integrated command chain.

The political order that developed out of this power-sharing exercise is characterized by intense and sometimes violent power competition, in particular in the eastern part of the country, where violence at various levels of intensity is ongoing. In the immediate post-settlement period, politico-military entrepreneurs struggled to maintain and extend the political, economic and military spheres of influence they had carved out during the wars, both within and outside the state apparatus. At the same time, the various competing factions tried to take advantage of the new political constellation by repositioning themselves in the national and sometimes also regional political and military arenas. A common method of such repositioning was participation in electoral politics, notably the 2006 and 2011 presidential and parliamentary elections. However, the electoral and wider political inclusion of former warlords is generally believed to have contributed to the ongoing violence in the east, in part by creating incentives among those with poor electoral prospects and results to take up arms. Furthermore, by reinforcing ethnic outbidding, it is said to have provided an impetus to armed mobilization along ethnic lines (Stearns et al. 2013).

Without contradicting these observations, this chapter intends to refine the analysis of how the electoral and wider political inclusion of ex-belligerents has contributed to the militarization of the eastern Democratic Republic of the Congo (henceforth the Congo). By exploring the post-settlement trajectory of one particular politico-military entrepreneur, Antipas Mbusa Nyamwisi, it shows how even political actors with relatively good electoral prospects and results, and who do not explicitly draw upon antagonistic ethnic discourses, have contributed to ongoing violence. During the Second Congo War, Mbusa was the president of the insurgent movement Congolese 
Rally for Democracy/Kisangani-Liberation Movement (Rassemblement Congolais pour la Démocratie/Kisangani-Mouvement de Libération, RCD/K-ML), the main stronghold of which was the Grand Nord area, encompassing Beni and Lubero territories in the north of North Kivu province. After the signing of the final peace accord, the RCD/K-ML was transformed into a political party, of which Mbusa became the president. Mbusa was subsequently appointed minister in the transitional and first post-transitional governments, and stood for president in both the 2006 and 2011 elections. In 2011, he also ran for election as a member of parliament (MP). However, whereas in 2006 the RCD/K-ML participated as part of a platform of progovernment parties, in 2011 it ran on an opposition ticket, reflecting the growing rift between Mbusa and Congo's President Joseph Kabila.

This switch to the opposition can be attributed both to the changing position of Mbusa Nyamwisi in the national and provincial political landscape and the strategies he devised for navigating these arenas. Mbusa reigned supreme over the RCD/K-ML and therefore had preponderant influence in determining the party's course. In continuity with the war era, his strategies largely followed the logics of "brokerage" and "multipositioning": he maintained contacts with nominally opposed factions, whether in the political or military domain, which enabled him to reinforce his negotiation position by threatening to intensify links to other factions' enemies. Furthermore, Mbusa positioned himself at once locally (in the Grand Nord, and subareas thereof), provincially (North Kivu), nationally (Congo) and regionally (Great Lakes area). This multi-positioning allowed him to play a role as gatekeeper to and broker between different types of networks located at different levels.

Since Mbusa's strategy of multi-positioning and brokerage included maintaining ties with armed groups and military figures, his post-settlement quest for power had important security effects. But rather than manipulating armed groups directly, he mostly maintained low-key, secretive contacts, creating a veil of mystery surrounding his dealings. Yet in a climate awash with rumors, tensions and violence, mere suspicion of links to armed actors has direct security effects, for instance prompting opposing factions to militarily reinforce their position. Furthermore, in the militarized political-economic order of the eastern Congo, the ability to manipulate armed actors is a valued currency, as it often translates into enhanced negotiating power. By demonstrating the value of this currency, although with diminishing effectiveness, Mbusa's ways of navigating the post-settlement order have importantly contributed to its ongoing militarization, and therefore to the manifestations of organized violence that this militarization entails. As such, Mbusa's political dealings are reminiscent of the classic strategy of the pompier-pyromane (firefighter-pyromaniac), referring to the firefighter who lights fires in order to capitalize upon his or her own capacity to extinguish them.

While Mbusa's personal agency has been an important factor in determining his postsettlement trajectory, the latter has also been strongly shaped by the general politicalmilitary context. Therefore, the chapter sets out by sketching a number of general characteristics of the Congo's pre-war and post-settlement orders, and the two wars in between these periods. It then zooms in on Mbusa Nyamwisi, describing his personal career and the strategies he adopted both during the war and after the settlement, which are analyzed against the background of his position both in the RCD/K-ML and in the Grand Nord. The insights flowing from this analysis allow for drawing a 
number of conclusions on the effects of the political participation of politico-military entrepreneurs on the nature of the post-settlement political order, in particular its violent character.

\section{Two wars and two intransitive transitions}

The violent nature of political competition in the post-2003 era is not a novel phenomenon in the Congo. At regular conjunctures in the country's history, various forms of violence have played a pronounced role in channeling power struggles. One such period followed Mobutu's announcement of a transition to multiparty democracy in 1990. The subsequent limited and imperfect opening of political space intensified ethnic and armed mobilization. At the root of this hardening of the political climate was a complex interplay between, on the one hand, local-level inter-community tensions, often surrounding land and local authority, and on the other hand, manipulation by national and provincial politicians. This manipulation was partly fed by the divide-and-rule politics that Mobutu embarked upon to thwart the nascent democratization process (Mamdani 1998). One manifestation of this was géopolitique or an effort to balance political and administrative representation between different regional and ethnic groups. Géopolitique institutionalized competition between groups framed as "ethnic", and focused attention to the question of who was a "native" and could therefore represent a certain area, and who was not (Mararo 2005). A second strategy was the application of the pompier-pyromane scenario. This entailed stoking up animosities to the point that they turned violent, and then extinguishing them in order to reassert control, in this way reinforcing and demonstrating authority. The clearest application of this strategy was in the province of Shaba (now Katanga), where political manipulation fueled an ethnic cleansing campaign executed by radical youth militias that led to the expulsion of thousands of Kasaians, many of whom died, in 1992 and 1993 (Dibwe dia Mwembu 1999). While top-down manipulation was less evident in the case of the violence that flared up in North Kivu in 1993, which was strongly nourished by long-standing local tensions, the national political context did provide new incentives for armed mobilization, and the provincial politicians that played a key role as instigators were close allies of Mobutu (Mararo 2003).

Due to concerted efforts to derail the democratization process, not least by Mobutu, the announced introduction of a multiparty system heralded no more than an "intransitive transition" (de Villers and Omasombo 2002), which ultimately fostered exclusionary and violent politics. Yet despite managing to maintain the upper hand in this disorder, Mobutu was not to retain power for long. In 1997 he was ousted from power by an insurgent coalition backed by regional powers, the Alliance of Democratic Forces for the Liberation of Congo-Zaire (Alliance des Forces Démocratiques pour la Libération du Congo-Zaïre, AFDL). Within less than seven months, the insurgents managed to capture Kinshasa, thereby ending the First Congo War (1996-1997). However, the new regime that was installed under Laurent-Désiré Kabila soon fell out with its erstwhile backers, in particular Rwanda and Uganda. The latter therefore engineered yet another rebellion, that of the Congolese Rally for Democracy (Rassemblement Congolais pour la Démocratie, RCD), which erupted in August 1998. This inaugurated the Second Congo War (1998-2003), which grew to be a complex mixture of a regional war that drew in no fewer than seven African countries, a variety of civil wars that were fought on Congolese soil, and a myriad of 
local conflicts that turned violent. The Congo became a patchwork of politicalmilitary orders, having a government-held zone in the west, and a host of rebel-held areas in other parts, most of which were further fragmented due to the presence of dozens of small-scale armed groups, often labeled "Mai-Mai". The most important Congolese rebel movements were the Uganda-backed Movement for the Liberation of the Congo (Mouvement pour la Libération du Congo, MLC) in the northwest, and the RCD in the east. However, the RCD gradually fell apart into three factions due to power struggles and differences in political vision and strategic preferences, both between and among its foreign supporters and their Congolese clients. While the core group of the RCD, supported by Rwanda, controlled the province of South Kivu, and parts of the provinces of Maniema, Katanga and North Kivu, specifically its southern part, a Uganda-backed branch, which gradually morphed into the RCD/K-ML, had its fiefdom in the Grand Nord. A smaller faction called RCD-National, which was also sponsored by Uganda, operated to the north of that, in Orientale Province (Lanotte 2003; Stearns 2011).

The multitude of belligerents involved in the Second Congo War severely hampered the implementation of the final peace accord and related power-sharing arrangements. The signatories were a motley crew comprised of the following parties: the Congolese government, since 2001 headed by President Joseph Kabila in the wake of his father's assassination; the "unarmed political opposition" regrouping twenty-eight different political parties; the somewhat nebulous category of "civil society"; and finally five armed players, one of which, the so-called "Mai-Mai entity", consisted of a loose amalgam of myriad armed groups. All these factions vied for position not only between, but also among themselves, which both exacerbated existing internal divisions and generated new ones. This power competition compounded policy processes, not least because it polarized decision-making bodies. The transitional presidency, comprised of one president and no fewer than four vice-presidents from different factions, was no exception to this. This so-called " $1+4$ " formula was emblematic of the entrenched factionalism, power grabbing and political paralysis that were a hallmark of this second transition, as epitomized by the widely circulating pun " $1+4=0$ " (Willame 2007).

Aside from the power struggles, the transition was also hampered by the slow pace and problematic nature of the military integration process. In order to maintain their military spheres of influence, several belligerents withheld (a part of) their troops from integration. This was for instance the case with Mai-Mai groups that had only local spheres of influence and constituencies, and lacked connections and clout at the national level. Similar foot-dragging could be detected among larger groups that were marginalized in the presidential patronage network and stood little chance in the elections, but had relatively autonomous sources of revenue, for example controlling trans-border trade networks or having direct outside support. To such groups, which included a part of the RCD, the main strategy of navigating the transition was to maintain a powerbase predominantly outside of the centrally controlled state apparatus. Consequently, they withheld a part of their troops from the military integration process. Other groups, by contrast, invested heavily in the political games played out in the new national political arena, and were more willing to send their troops into the national army. This did not imply, however, that they readily ceded control over their local strongholds or entirely gave up independent military capacities. Rather, they mostly changed the modalities of maintaining control, trying 
to manipulate the national and local state institutions, including the national armed forces. They maintained networks of loyal officers within the army, leading to parallel command chains and divided loyalties. For example, the MLC initially held on to a large separate security guard to protect its president. Some factions also resorted to non-state channels to retain a capacity for militarized maneuvering, such as liaising with foreign rebel groups or local militias (Verweijen 2014). As will be further explained below, this was also the strategy followed by parts of the RCD/K-ML.

The ex-belligerents' half-hearted commitment to military integration importantly contributed to the ongoing militarization of politics, prompting competing factions to turn to (threats of) force or army disintegration to reinforce their political position. As this strategy was often successful, a system emerged in which political actors had incentives to take up arms (Eriksson Baaz and Verweijen 2013). The continued existence of (semi-)autonomous military forces both within and outside of the national military also perpetuated the militarization of the economy in the east, as these armed actors underpinned - either directly or indirectly - the coercion-based control of production and trade networks. Electoral politics added significant volatility to this toxic mix. The post-settlement Congo became a competitiveauthoritarian order (Matti 2010), where those linked to the presidential patronage network have preferential access to coveted positions in the state apparatus. This confines the opposition to positions of lesser influence, mainly in the toothless parliament. The result is a zero-sum game political environment, where access to the government and presidential patronage network is the highest price. In the militarized context of the eastern Congo, such a political environment incentivizes those faced with bleak electoral prospects or results to manipulate armed actors. This could most clearly be observed among the RCD, whose poor electoral prospects contributed to the group's disintegration, prompting a dissident faction to launch a new rebellion, the National Congress for the Defense of the People (Congrès National pour la Défense du Peuple, CNDP) (Stearns 2013a).

The potential for electoral processes to have destabilizing effects is further reinforced by the strong ethnic and regional identity-based character of political mobilization in the Congo (Ngoy-Kangoy 2007). On occasion, this translates into ethnic outbidding, which may include the manipulation of non-state armed groups formed along ethnic lines. Electoral politics also contributes to volatility by fostering the severe fragmentation of the political landscape, which intensifies power competition. Based on proportional representation with open-list, multi-member constituencies, ${ }^{1}$ the electoral system promotes a focus on candidates rather than programs. This focus is further reinforced by the personalization of politics and the absence of a tradition of party politics with parties grounded in well-articulated political visions (NgoyKangoy 2006). No fewer than 9,709 candidates stood for the 2006 elections, a large part of whom ran as independents. Furthermore, from the around 269 parties registered at that time, sixty-seven entered the 500-seat legislature (Carter Center 2007). The first legislative elections organized after the transition, in 2011, were characterized by an even more pronounced fragmentation: while 18,386 candidates participated, ninety-eight of the registered 417 political parties entered the national assembly, of which seventy-six had five seats or less (Carter Center 2011). A similar fragmentation is visible in the military sphere, at least in the eastern Congo, home to several dozens of domestic and foreign armed groups of all stripes. This multifaceted fragmentation has created a climate in which forging and changing political and 
military alliances have become important power strategies.

It can be concluded that the 2003-2006 period has largely turned out to be yet another "intransitive transition", not having induced a significant transformation of the patronage- and violence-based political order of the pre-settlement era (Vlassenroot and Raeymaekers 2008). Although operating in a different context and with a different style than Mobutu, President Joseph Kabila similarly relies on a combination of coercion and doling out patronage-related benefits via personal networks, even while his control over the coercive apparatus is tenuous. Yet, as the post-settlement trajectory of Mbusa Nyamwisi clearly demonstrates, the presidential patronage network has sufficient weight to heavily shape political actors' position in the political landscape, and those who are marginalized by this network suffer serious losses of influence. Militarized maneuvering can only partly undo such marginalization.

\section{The trajectory of Antipas Mbusa Nyamwisi: champion of double-dealing}

As an amalgamation of elites with different political visions and interests, the RCD rebellion was never a coherent movement. In March 1999, then leader Ernest Wamba dia Wamba, a former university professor who was strongly backed by Ugandan President Yoweri Museveni, was ousted from the movement. He established himself in the city of Kisangani, where he engineered his own branch of the RCD with the help of Uganda, eventually called the RCD-Liberation Movement (RCDKisangani/Mouvement de Libération, RCD-K/ML). Soon after, a definite falling out between Uganda and Rwanda, leading to heavy clashes in the city of Kisangani, forced the movement to set up its headquarters in the town of Bunia (in Orientale Province) to the east. It was here that a vicious and at times violent leadership struggle started that would end in Mbusa Nyamwisi taking over the presidency of the movement in November 2000, in what has generally been described as a coup d'état that triggered fierce fighting (International Crisis Group 2000). Mbusa is a politician of Nande origins, representing the single largest ethnic group in the province of North Kivu. The Nande are concentrated in the Grand Nord, but also have a substantial presence in Orientale. Reflecting the ethno-regional character of his primary support base, Mbusa decided to establish the headquarters of the movement in Beni, an important trade center in the Grand Nord close to the Ugandan border.

The bumpy road to prominence Mbusa had started his political career in the shadow of his brother Enoch Muvingi, who had been a ministerial adviser and minister in various governments under Mobutu. Enoch was also one of the founders of the political party Federalist Christian Democracy (Démocratie Chrétienne Fédéraliste, DCF), which was formed after the opening of political space in 1990 . He led the DCF/Nyamwisi, which had a mostly Nande constituency, but was a member of the wider Christian Democrat political family. Muvingi reached the apex of his power during the transition, when géopolitique led to the marginalization of the Banyarwanda in the provincial and national political institutions. The term "Banyarwanda" refers to Hutu and Tutsi, and both groups are "Rwandophones" or speakers of Kinyarwanda language. ${ }^{2}$ The Banyarwanda, an amalgam of heterogeneous groups, are the second largest category in North Kivu, and have been involved in a long-standing struggle with the Nande for political and economic preponderance at the provincial level (Mararo 2003). Muvingi tried to capitalize upon this struggle, 
hoping to draw popular support by propagating antagonism against the Banyarwanda. He also supported a variety of militias to reinforce his power, thereby constituting an early example of a politico-military entrepreneur. These included the Kasindiens, located in the home base of the Nyamwisi family, the Rwenzori region, and the Bangilima, who operated as a type of youth militia of the DCF/Nyamwisi (Mararo 2003). Discovering the political and economic leverage obtained through contacts with armed actors, Muvingi volunteered to become a broker between Mobutu and the Ugandan rebels of the National Army for the Liberation of Uganda (NALU) based in the Ruwenzori mountains. Mobutu intended to employ this group to weaken Ugandan President Museveni, a political leader he profoundly disliked (Raeymaekers 2009). This shows that the militarization of politics in the eastern Congo had already started before the outbreak of the wars.

When Enoch Muvingi was assassinated in 1993, Mbusa became his political heir, assuming the position of secretary general of the DCF/Nyamwisi. Although he lacked the charisma and rhetorical skills of his brother, he took direct inspiration from the militarized strategies of power politics and multi-positioning the latter had pioneered. However, Mbusa did not immediately embark upon a political career, being initially more active in the long-distance trade with East and Southeast Asia. His political star first started to rise after he allied himself with the AFDL, the regional-domestic insurgent coalition that toppled Mobutu in 1997, of whose plans he was informed during a meeting with Museveni in Uganda in 1996. When learning of Uganda's intention to get involved in the second insurgency that started in 1998, he again seized the opportunity and became one of the RCD's founding members (Omasomba et al. 2009). While his exact motives for this move are unknown, it seems that personal ambitions and the opportunities that unfolded due to his regional contacts played an important role.

The splits and power struggles within the RCD and its offshoots subsequently offered Mbusa yet more possibilities for advancing his career. The strong dominance of Banyarwanda in the Rwanda-backed RCD wing established in Goma allowed him to play upon fears among the Nande population about the growing power of this group. Mbusa was also well positioned within the powerful Nande business community, which has traditionally thrived on forms of cross-border trade under favorable tax regimes resulting from the manipulation of rules and regulations. Additionally, he could draw on the networks and reputation of his deceased brother, the politician Enoch Muvingi. What further consolidated his power was that he managed to build up close ties with key figures in the militarized trans-boundary economic networks that developed in the course of the war, often building on pre-existing economic configurations. Thus, he maintained friendly relations with certain Ugandan businesspeople and officers of the Ugandan armed forces, like General James Kazini and Museveni's half-brother Salim Saleh (International Crisis Group 2003). In combination with aggressive political maneuvering, this powerbase allowed him to eventually take over the leadership of the RCD/K-ML. Although Ugandan President Yoweri Museveni disliked Mbusa and the form of ethnicized politics that he represented, clearly favoring the more ideologically oriented Wamba dia Wamba, he eventually accepted the power takeover largely for pragmatic reasons (International Crisis Group 2000).

Multi-positioning and brokerage In comparison to the much bigger RCD to the 
south, the RCD/K-ML was a second-tier politico-military movement. It exercised weak and contested control over the Nande-dominated territories of Beni and Lubero, not least due to strong divisions among the Nande and between the Nande and minority groups, while also having a zone of varying influence in Orientale Province. Its military wing, the Congolese Popular Army (Armée Populaire Congolaise, APC), numbered around 3,000-5,000 troops, and functioned as a conventional army with a core of partly Uganda-educated officers (International Crisis Group 2006). It was placed under the control of the political executive, which was presided over by Mbusa Nyamwisi and two vice-presidents, who directed a number of commissaires or ministers with various portfolios. However, these ministers had little influence, as Nyamwisi and a small clique around him had preponderant power over the movement. Similarly, the congress of the RCD/K-ML, formally erected to represent the base, had a mostly symbolic character (Raeymaekers 2007).

Rather than creating entirely new administrative structures, the RCD/K-ML administered the Grand Nord by means of influencing existing agencies via a combination of patronage politics, coercion and evasion, or the bypassing of the administration by seeking new channels, notably in the business sector. While this allowed the movement to have a reasonable degree of influence, it diminished its chances of gaining widespread support and legitimacy, focused as it was on co-opting business and administrative elites. Overall, the movement had limited popularity outside the circle of those directly benefiting from its economic governance. It was, for example, strongly contested by players like the influential Catholic Church and the Mai-Mai militias that mushroomed in the countryside (Raeymaekers 2007). This situation strongly shaped Mbusa's strategies and paths of action, both during the war and in the post-settlement era.

In order to ensure the support and tap into the resources of the Nande business community, a crucial constituency that was however not particularly keen on getting involved in insurgent politics, the RCD/K-ML administration seized upon the existing system of pre-financing that had been pioneered by customs agencies. Under this system, economic operators were granted tax exemptions in return for fixed prepayments on customs duties in cash. Engaging in such arrangements was mutually beneficial, as it gave the RCD/KML income and allowed traders to continue their business activities in a beneficial tax and security climate. Since the income of the $\mathrm{RCD} / \mathrm{K}-\mathrm{ML}$ thus came to depend directly on the flourishing of the business community, the movement had vested interests in guaranteeing property rights and the safety of important trade routes. At the same time, its dependence on economic operators allowed the latter to remain relatively autonomous vis-à-vis the insurgents, which enabled them to play a growing role in the provision of public goods like infrastructure (Raeymaekers 2007). The resulting business-friendly climate led to significant prosperity for some, generating a construction boom in the Grand Nord's main towns of Beni and Butembo, for instance. This boom was further promoted by the RCD/K-ML's policy of exempting building materials like cement from import duties, a measure that was partly intended to win popularity. A similar rationality motivated other tax cuts, fostering an overall beneficial fiscal climate. ${ }^{3}$ However, large parts of the population of the Grand Nord were excluded from the spoils, or even saw their income drop drastically, as rampant insecurity in the countryside hampered agricultural production and trade (Raeymaekers 2004). Furthermore, much prosperity was generated via economic networks that engaged in coercive and illegal 
strategies of accumulation, such as theft, tax fraud, manipulation of the money supply and the instrumentalization of local militias to control resource-rich areas. Much of the benefit accrued to Ugandan economic operators, most of whom were exempted from tax payments, leading to accusations of resources plunder (UNSC 2002).

Insecurity in the countryside was partly the result of the activities of numerous MaiMai groups, which mobilized around narratives of resistance against foreign influence. These groups were often instrumentalized by local strongmen, like economic operators and customary chiefs, to reinforce their position in local conflicts and the economy. Certain groups also received support from figures in the Catholic Church, which had tense relations with the Protestant Nyamwisi. While many MaiMai groups, like Muhola and Vurundo, occasionally clashed with Mbusa's forces, some would at times also collaborate with them, following the complex pattern of ever-changing alliances between a multitude of domestic and foreign armed actors that characterized the Second Congo War (Belaid 2015). In the RCD/K-ML's area of influence, foreign forces did not only include the Ugandan military, but also the remnants of the NALU, which had by then fused with another Ugandan rebel group named Allied Democratic Forces (ADF) (Titeca and Vlassenroot 2012). Despite numerous counterinsurgency operations by the Ugandan military, this group continued to retain substantial capacity for nuisance, including within Uganda.

While changes of alliances were ongoing, some were more important than others. One of the most significant shakeups of the political-military landscape occurred at the end of the year 2000, when Uganda tried to reunite the three major insurgent movements it sponsored in the Congo (the MLC, RCD/K-ML and RCD-N), proposing Jean-Pierre Bemba, the leader of the MLC, as the president of the united movement. Experiencing this as a direct threat to his leadership, Mbusa decided to sabotage the reunification attempt, leading to intense fighting in the course of 2001 (International Crisis Group 2003). Realizing he would be in a weak position if the other two movements formed a common front against him with the support of an increasingly hostile Kampala, he decided to play a new card and approached Kinshasa. ${ }^{4}$ The same repositioning prompted the RCD/K-ML to reinforce contacts with the ADF-NALU (International Crisis Group 2007), which helped to gain further leverage vis-à-vis Uganda. This shows how Mbusa's war-era strategy consisted essentially of two components. First, "multi-positioning", or flexibly maintaining contacts with numerous often nominally opposed factions, and then gaining leverage by changing or threatening to change alliances. Second, "brokerage", or deriving political capital from having and controlling access to different networks and groups located in various arenas and at various scales (local, provincial, national, regional). ${ }^{5}$ These strategies were partly born out of weakness, with the RCD/K-ML lacking comprehensive political and military control, while enjoying only limited popularity (Raeymaekers 2004).

\section{Transitional dealings and electoral posturing: sort of running for president}

Mbusa's 2001 rapprochement with Kabila was not only the product of the changing strategies of Kampala. It was also related to the new dynamics generated by an acceleration of the peace process and the looming of a negotiated settlement based on the principle of power-sharing. By placing his bets on an alliance with Kinshasa, Mbusa hoped to entrench his rather tenuous grip over his fiefdom and secure his place in the transitional order. This strategy was largely successful: Mbusa became well positioned in the presidential patronage network, allowing the RCD/K-ML to obtain a 
significant number of posts in the transitional institutions. The party was granted two ministerial and two vice-ministerial posts, important appointments in the public enterprises, fifteen out of 500 seats in the general assembly, and considerable weight in the provincial administration of North Kivu. Mbusa Nyamwisi became minister of regional cooperation, allowing him to build on and extend his network of regional contacts. ${ }^{6} \mathrm{He}$ also capitalized on his privileged access to the presidential circle, which enabled him to play a role as broker between his local networks in the Grand Nord and politicians at the national level. In continuity with the personalized and patronage-based politics that had been a hallmark of the RCD/K-ML in its insurgent years, it was mostly Mbusa who decided on appointments in the national institutions, a discretionary power that significantly reinforced his position among his local constituency. ${ }^{7}$ At the same time, this intermediary role meant that Kinshasa had to go through him to exercise influence over the Grand Nord, rendering him an indispensable ally in the reunification process.

Kinshasa's dependency on Mbusa's brokerage granted the RCD/K-ML and its wider networks a relatively high level of autonomy, which allowed them to maintain a predominant influence over the customs, border control and intelligence agencies in the Grand Nord, in particular at the border post of Kasindi. In this manner, Mbusa was able to guarantee the continuation of a favorable fiscal climate, and thereby to secure the support of the trans-border trade networks that were at the heart of the RCD/K-ML's powerbase. However, since these networks thrived on protection agreements and locally negotiated tax reductions, they deprived the political center of important sources of revenue. Kinshasa's position was however too fragile to seek an immediate showdown, not least since the RCD/K-ML's position of relative autonomy was backed up by continuing coercive control. Throughout the transition, the Grand Nord was controlled by the 88th and 89th brigades, which were predominantly composed of APC troops, although these were now formally part of the new national armed forces, the Armed Forces of the Democratic Republic of the Congo (Forces Armées de la République Démocratique du Congo, FARDC) (Meece 2006a). It was only after the 2006 elections that a part of these troops departed in order to participate in the military integration process, leading to their replacement by FARDC Integrated Brigades, composed of soldiers of various ex-belligerent factions (Dougherty 2006). However, many ex-APC troops remained quasi-demobilized in the Grand Nord, guarding their uniforms and $\mathrm{arms}^{8}{ }^{8}$ while others were sent into the forest to form a new group (UNSC 2016). This "reserve force" was in contact with ex-APC officers who had integrated into the FARDC, but continued to further factional interests.

The transition allowed Mbusa to consolidate his position not only vis-à-vis Kinshasa, but also within the Grand Nord, capitalizing upon his control over the RCD/K-ML's access to the national political-administrative arena. He had even started to gain somewhat in popularity, being applauded as a "pioneer of national reunification". He was also credited with having reinforced the Nande's political representation and influence at the national level, as exemplified by the elevation of Beni and Butembo to the status of city during the transition, a long-standing demand of the Nande. ${ }^{9}$ Emboldened by his strengthened position, Mbusa decided to stand for president during the 2006 elections, despite his limited popularity outside the Grand Nord. This decision is likely to have been influenced by his expectation to run on the ticket of a broad electoral alliance under the name of Forces du Renouveau (Forces for 
Renewal). This strategy, however, largely fell through, as certain key factions declined to join the alliance. Crucially, Mbusa's main partner, Olivier Kamitatu of the Alliance for the Renewal of the Congo (Alliance pour le Renouveau du Congo, ARC), rallied to the electoral platform linked to the incumbent, the Alliance for the Presidential Majority (Alliance pour la Majorité Présidentielle, AMP). Realizing he had few other options, Mbusa decided just before the elections not to compete with the incumbent, encouraging his constituency to vote for Kabila, while campaigning with the Forces du Renouveau as part of the AMP (Meece 2006b).

Post-transitional waxing and waning While implemented last-minute, this altered electoral strategy paid off: the Forces du Renouveau, which also regrouped the DCF/Nyamwisi, closely allied to the RCD/K-ML, obtained three ministerial and three vice-ministerial positions in the new government, and twenty-eight out of 500 seats in the national assembly. Mbusa was rewarded for his move to the Kabila camp with a ministerial post of vital importance, that of Foreign Affairs and International Cooperation. ${ }^{10}$ Provincially, too, the RCD/K-ML managed to hold on to its influence. This became particularly clear in the battle for the position of governor of North Kivu, who is elected by the provincial assembly. Aside from giving access to power, the position of governor has a high symbolic value, reflecting who has predominant influence at the provincial level. It had therefore been a thorn in the Nande's flesh that during the transition the position had been occupied by a Hutu issuing from the Rwanda-backed wing of the RCD. These high political and symbolic stakes prompted the RCD/K-ML to engage in concerted efforts to push through its own candidate, despite the fact that the AMP supported another Nande politician, Jean-Chrysostome Vahamwiti Mukesyayira. Wary to let this crucial position slip out of its hands, the $\mathrm{RCD} / \mathrm{K}-\mathrm{ML}$ mobilized its contacts in the Nande business community to gather the funds and harness the pressure needed for a favorable outcome of the gubernatorial elections. ${ }^{11}$ On 27 January 2007, Julien Paluku Kahongya, member of RCD/K-ML and protégé of Mbusa Nyamwisi, was elected with twenty-five out of forty-two votes. $^{12}$ These results indicate that although linked to the ruling platform of the AMP, the RCD/K-ML had managed to maintain an autonomous powerbase at the level of North Kivu.

This base would soon start to erode. At the end of 2008, after a government reshuffle following the demission of Prime Minister Antoine Gizenga, Mbusa lost his prestigious job as minister of foreign affairs, being appointed to the much less influential post of Minister of Decentralization and Spatial Planning. The reasons for this demotion are difficult to fathom, but could well be linked to the general tendency in patronage-based systems to ensure regular rotations of office with an eye to avoiding clients building up too much autonomy (see Bayart [1989] 2006). In this case, it is possible that Kinshasa hoped that weakening Mbusa, already seen as dissident by pushing through his own candidate for governor, would allow them to reinforce their grip over the political-economic networks in the Grand Nord that continued to deprive it of important revenues. Mbusa, however, was unwilling to allow the political center to encroach upon his sphere of influence, adopting an increasingly antagonistic stance vis-à-vis the Kabila government, which he accused of corruption and opportunism. Having less to distribute to his networks in terms of influence and access to positions at the national level, he gradually started to lose standing both within his party and among his wider constituency in the Grand Nord (Brock 2009). Increasingly distributing the scarce available resources among his inner 
circle only, criticism of his leadership grew, as it highlighted his penchant for clientelism and autocratic tendencies. ${ }^{13}$ These developments caused certain groups in the party, like the boyomais (referring to inhabitants of Orientale Province) political cadres and party membership, to feel increasingly marginalized. Although the majority of the RCD/K-ML's national MPs had been elected in Orientale Province, it was predominantly Nande from the Grand Nord who were granted access to positions of importance at the national level. These exclusionary tendencies eventually caused certain politicians to leave, thus undermining the party by weakening its base (Jokanko no date).

Mbusa's popularity among his electorate in the Grand Nord was similarly on the wane, fed by growing dissatisfaction about his mediocre efforts to improve the quality of governance and the weak performance of the Kabila government more generally. Insecurity in the Grand Nord remained rampant, as multiple Mai-Mai and foreign armed groups, notably the ADF, continued to operate, often with the support of political and economic actors who appealed to these groups to reinforce their position. Mbusa was not immune to that logic, allegedly maintaining contacts with certain armed group commanders and ex-APC officers in the FARDC who were linked to the ex-APC "reserve force". ${ }^{14}$ This militarized power complex, in turn, reinforced the mobilization of competing groups, such as the Mai-Mai led by Kakule Sikuli Lafontaine. However, like many other Mai-Mai groups, Lafontaine claimed to be in the bush to counter the influence of the CNDP, an important Tutsi-led armed group operating in the southern part of North Kivu (Belaid 2015). In the face of the operational weaknesses of the FARDC, the specter of the CNDP induced an informal policy of encouraging or tolerating secret alliances with other armed groups (Stearns 2013b). This policy is likely also one of the reasons why few steps were undertaken to investigate allegations of continuing contacts between parts of Mbusa's network and the ADF, reported to run via Mbusa's brother Edouard Nyamwisi, the chief of Ruwenzori sector (Mwanawavene et al. 2006). While there were several indications that these links existed, Kinshasa undertook no action, in part because it believed that the ADF could function as a bulwark of last resort against CNDP influence (Titeca and Vlassenroot 2012). Whether real or imagined, these presumed contacts with armed groups gave Mbusa Nyamwisi political leverage both in Kinshasa and in Kampala, which still feared the ADF. Believing that Mbusa could ultimately muster a certain influence over these groups, he continued to be seen as indispensable for maintaining regime security, in spite of his diminishing weight in formal political institutions. $^{15}$

In sum, similar to other important political figures with a rebel background, Mbusa Nyamwisi's post-settlement strategies have remained firmly marked by a militarized logic, leading him to maintain contacts of a varying nature with different armed actors. While not hesitating to feed into and instrumentalize divisions, Mbusa has, however, largely refrained from stoking up ethnic antagonisms by employing extremist rhetoric. Certainly, as an important incarnation of the Nande's aspirations, he regularly appealed to their competition with and dislike for Rwandophones, not hesitating to characterize the latter in stereotypes and ascribe them evil intentions (see for example Brock 2009). However, he has employed such narratives generally more in internal power competition, accusing fellow Nande of being complicit with Rwandophones, than to directly target Rwandophones themselves. ${ }^{16}$ Hence, especially in comparison with more radical voices, he has been relatively moderate, 
and is not known for grounding his influence in fueling ethnic tensions. Yet this moderation has done little to assure him popularity, and might have even undermined it.

Slipping toward the opposition With his influence and popularity steadily on the wane, and feeling increasingly hostile towards Kabila, Mbusa embarked upon a dangerous move. On 24 May 2010 he created a political platform called Liberal and Patriotic Center (Centre Libéral et Patriotique, CLP) together with three other ambitious and outspoken politicians who were also linked to the AMP (progovernment alliance). ${ }^{17}$ While interpretations of the reasons behind this initiative vary, it is generally believed that it was born out of dissatisfaction with the performance of Prime Minister Muzito and the government in general, and the desire to influence the appointment of his successor, not least out of personal ambition. At the same time, it was a way of political repositioning in the face of the upcoming general elections, including for Mbusa, who hoped it would help counter his marginalization. Enraged by the initiative, which posed a clear threat to his power, President Kabila abruptly broke off a journey to Egypt and called an emergency meeting at Kingakati, his private ranch east of Kinshasa, on 26 May 2011. Not holding back his anger, he gave what the media called "the gang of four" an ultimatum to end what he saw as a secessionist attempt within the AMP, a threat that was sufficiently serious to prompt "the gang" to immediately withdraw (Le Potentiel 2010; La Prosperite 2010). In the case of Mbusa, the damage done to his relations with Kabila appeared irreparable, leading him to quit the AMP. Not surprisingly, in the next cabinet reshuffle in September 2011, he was not reappointed as minister. Aside from destroying his relations with Kabila, the CLP adventure caused further dissension and divisions within the RCD/K-ML, as Mbusa had embarked upon the initiative without consulting the party. ${ }^{18}$

A similar controversy was sparked by Mbusa's rather unexpected and last-minute decision to run for president in the 2011 elections. As in 2006, this plan seems to have been informed by his anticipation of a great electoral coalition, this time of all opposition candidates. However, as with previous strategic moves, he failed to consult the party, some factions of which doubted the wisdom of his candidacy given the lack of time and resources for campaigning. ${ }^{19}$ Hence, this electoral adventure further illustrates how the RCD/K-ML served to a large extent as a vehicle for Mbusa's interests, with his powerbase being ultimately grounded more in economic networks in the Grand Nord than in the party. As in 2006, Mbusa's expectations concerning the possibilities to forge an electoral coalition proved too optimistic, and the opposition eventually failed to unite. In combination with his own lack of preparation, this made him decide to advise his electorate to vote for the opposition figure Étienne Tshisekedi, although he did stand as a presidential candidate himself. In the Grand Nord his advice was overwhelming followed, although a fair share of the electorate still voted for Mbusa himself, ${ }^{20}$ allegedly as a result of a last-ditch effort by the Butembo business community to mobilize voters. ${ }^{21}$ This support also helped him draw a large number of votes in the legislative elections, allowing him to become MP for the constituency of the city of Butembo. In general, the RCD/K-ML did relatively well in the 2011 legislative elections, obtaining six seats in the national assembly, while sister party DCF/Nyamwisi managed to get three (CENI 2012). At the root of this relative success was a general disappointment with the Kabila government in the Grand Nord, causing the electorate to overwhelmingly support the RCD/K-ML's 
move to the opposition.

However, in light of the zero-sum nature of politics in the Congo, where the government camp virtually monopolizes power, the move to the opposition created hardship for the party and Mbusa's personal networks. Barred from access to positions of importance, they experienced a steep decline in influence and income, making it increasingly attractive to switch sides. The possibilities to do so were greatly enhanced when governor Julien Paluku, who had been elected to the national assembly in 2011 on an RCD/K-ML ticket, announced the creation of his own party shortly after the elections, the United Bloc for the Renaissance and Emergence of the Congo (Bloc Uni pour la Renaissance et l'Emergence du Congo, BUREC). Due to his function of governor, and his favorable position in the presidential patronage network, it was henceforth Paluku who controlled the Nande's access to the state apparatus, albeit more at the provincial than the national level. This was a desirable scenario for Kabila, allowing him to gradually weaken the RCD/K-ML, and therefore the quasiautonomous economic networks depriving Kinshasa of income. Compared to Mbusa, Paluku has less influential connections in the Nande business community and at the regional (Great Lakes) level, and fewer capabilities for mobilizing (threats of) force, since he lacks connections to ex-APC officers or armed groups. Consequently, he depends to a large extent on Kabila's patronage for the exercise of power, rendering him a loyal client.

With political mobilization in the Congo continuing to follow regional-ethnic lines, it was clear that Paluku depended on the same constituency as the RCD/K-ML. In an effort to rally its cadres to his own party, he employed a strategy of carrots and sticks, including threats to purge the administrative apparatus of those who would not change political color. This led to what is generally called the burecation of the provincial and local institutions. ${ }^{22}$ That this strategy was successful is powerfully evidenced by the decision of the mayors of Beni and Butembo to change political camps, since both these cities used to be important strongholds of Mbusa. Burecation also touched upon the posts that guarantee the semi-autonomous functioning of Nande economic networks, such as the customs and import/export control agencies based in Kasindi or the provincial financial service of the Directorate-General for Revenue-North Kivu (Direction Générale des Recettes-Nord Kivu, DGR-NK). Hence the presidential patronage network has tried to seize upon the RCD/K-ML's waning influence to weaken the network's hold over the Kasindi border post, appointing loyalists either directly or via Paluku, who has a growing influence over appointments.23 In this manner, the already heavily divided Nande community has become subject to further political rifts.

Misguided militarized posturing: flirting with the M23? Mbusa's efforts to deal with the waning influence of the RCD/K-ML have only reinforced political divisions among the Nande. In 2012, parts of the CNDP, which had integrated into the FARDC in 2009, mutinied and started a new rebellion, the Movement of 23 March (Mouvement du 23 Mars, M23). This movement was sponsored by Rwanda, but there were also indications of limited and more passive involvement by Uganda, believed to largely run via presidential military adviser General Salim Saleh (UNSC 2012). This involvement appears to have been more driven by Kampala's wish to have leverage over an insurgency which was close to its borders and implicated its powerful neighbor Rwanda than to actively promote it. Furthermore, getting involved would 
render Kinshasa partly dependent on Uganda for efforts to manage the insurgency, thus allowing Kampala to enhance its regional sphere of influence. One way to achieve the desired leverage, so it seems, was to motivate old allies of Uganda within the RCD/K-ML to join or liaise with the M23. Given his role as gatekeeper to this network, Mbusa Nyamwisi was an indispensable figure in these efforts. He willingly seized upon this opportunity to reposition himself at the national and regional level, fabricating the impression that he was an essential figure for the rebellion's expansion, which gave him renewed importance in both Kampala and Kinshasa. Following his familiar strategy of double-dealings, he did not become openly allied to the M23 or actively involved in it, instead adopting a wait and see attitude and retaining a veil of mystery about his possible involvement. Thus he maintained a guarded silence from abroad, reportedly moving between South Africa and Tanzania after having gone into exile after leaving his post in parliament in 2012. His direct involvement in the M23 has therefore been difficult to prove, allowing his supporters to deny it and to ascribe the accusations to a smear campaign intended to crack down on the opposition (Nkole no date).

Yet several family members and former APC officers believed to be close to Mbusa did join the M23. ${ }^{24}$ In December 2012, Mbusa's brother Edouard Nyamwisi was arrested in Butembo on allegations of maintaining contacts with M23-linked networks. Furthermore, there are indications that Mbusa was involved in engineering a new coalition of Nande armed groups under the leadership of Hilaire Kombi, an exAPC officer who deserted from the FARDC in mid-2012. This group was reported to be in regular contact with M23, including via a liaison officer who also used to be in the APC (UNSC 2013). The mobilization of these military figures was relatively easy, given that many former ex-APC officers felt marginalized within the FARDC. These feelings were reinforced after the integration of the CNDP in 2009, which revived old resentments about Rwandophone domination of the command chain within the FARDC (Eriksson Baaz and Verweijen 2013). Furthermore, the large number of demobilized fighters in the Grand Nord, many of whom feel abandoned and disappointed with the post-settlement order, ensured that Hilaire and his coalition had no lack of recruits. ${ }^{25}$

Disappointment is not limited to military circles, but can also be found among the political cadres of the RCD/K-ML, who are in a dire position, being increasingly subject to the harassment and exclusion that befalls opposition parties in the Congo. ${ }^{26}$ Such generalized resentment creates fertile ground for politico-military entrepreneurs and the manipulation of armed mobilization. In January 2014, the FARDC launched large-scale military operations against the ADF with the support of the United Nations Mission in the DRC, MONUSCO. This military shakeup has unleashed profound instability. In the course of 2014 and 2015, a string of attacks on civilians took place, which killed over 550 people and displaced hundreds of thousands. Only a part of these attacks are believed to have been perpetrated by the ADF, as a form of revenge killings and military strategy (UNSC 2016). The inability to identify the perpetrators of these massacres has created general confusion and generated a stream of rumors that competing factions among the Nande and other groups in the Grand Nord are trying to manipulate, including the personal networks of Mbusa Nyamwisi, other factions in the RCD/K-ML, and allies of Paluku linked to the presidential patronage network. This last camp alleged that Mbusa was behind the horrendous attacks, supposedly through his M23 connections, and used this as a pretext to crack 
down further on his networks, in particular those running the parallel economic system of the Grand Nord. A number of high-profile businesspeople were arrested, and numerous RCD/KML-affiliated urban authorities in the city of Beni were replaced by members of pro-government parties. Mbusa loyalists in the RCD/K-ML, for their part, have tried to capitalize upon the instability by presenting it as evidence for Mbusa's crucial role in stabilizing the Grand Nord. Furthermore, they have attempted to lay the blame on Paluku, accusing him of collaboration with the ADF via the army general in charge of military operations against this group (Sweet 2015). Mbusa also resurfaced in the media, claiming to have superior knowledge about the attacks, thereby again creating an aura of mystery that has been typical of his operations (Rolley 2014). However, the accusations against Mbusa also reinforced efforts by competitors within the RCD/K-ML to oust him from power. These opposing factions intensified publicity efforts to highlight that Mbusa had already been expelled from the presidency and the party by the national political council in November 2013, in the wake of allegations of his involvement with the M23. The fact that these earlier efforts to expel him had limited effects demonstrates the extent to which Mbusa continues to be seen as an incarnation of the party (Forum des As 2014).

The efforts to influence the framing of the instability and in this manner discredit opponents, or what Mbusa himself aptly described in a radio interview at the end of 2014 as "politique des boucs-émissaires" (scapegoat politics), shows that the manipulation of insecurity to reinforce one's position does not only take place in a direct manner, by sponsoring violence, but also in more subtle ways. In the absence of certainty about the facts, allegations, rumors and names are manipulated and instrumentalized, causing a semblance of maintaining links to armed groups, or allegations of being involved in massacres, to be almost as effective a power strategy as openly maintaining these links or perpetrating violence itself. This type of rumor economy also allows for linking unrelated conflicts and animosities, and thereby strategically deploying various conflict narratives as a mobilizing resource (Sweet 2015). Perversely, these smokescreen tactics seem to both lower the costs and enhance the effectiveness of the pompier-pyromane strategy, allowing growing numbers of political-military actors to reap its fruits.

\section{Concluding remarks: the democratization of Pompier-Pyromania}

The Global and All-Inclusive Accord, the adoption of which signaled a formal end to the Second Congo War in 2003, created a new architecture for the Congo's political and security landscape. Ex-belligerents transformed into political parties and, after a brief period of power-sharing, participated in electoral politics. This chapter has focused on the post-settlement trajectory of one of the politico-military entrepreneurs participating in these transformations, Antipas Mbusa Nyamwisi, the leader of the former insurgent movement RCD/K-ML, reconstituted in 2003 as a political party. Between 2003 and 2011, Mbusa held a ministerial portfolio, while also standing as a presidential candidate in both the 2006 and 2011 elections, although more for symbolic considerations than in the expectation of winning. Furthermore, in 2011 he successfully ran for office as a national MP in the city of Butembo, traditionally one of his strongholds. On both occasions, he anticipated running as part of a broader platform, but each time this strategy fell through. Therefore, in 2006, he eventually took part in a pro-government alliance and in 2011 he went ahead as a standalone part 
of a fragmented opposition.

This shift towards the opposition at once reflected and further promoted his changing position in the political landscape, characterized by a growing marginalization within and eventual falling out of grace with the presidential patronage network.

Furthermore, it appears to be in part an outcome of the continuation of his war-era strategies of "multi-positioning" and "brokerage". These strategies consisted of forging links to multiple factions, including those nominally opposed, in various arenas, allowing him to serve as a gatekeeper and to gain leverage by constantly threatening to switch sides. Crucially, Mbusa served as an intermediary between Kinshasa and powerful Nande business networks in the Grand Nord, his main powerbase. In exchange for loyalty, he shielded this constituency from central state regulation and taxation. While this underpinned his power in the immediate postsettlement era, it became a source of frustration to the presidential patronage network in the medium term, as these networks deprived it of significant tax revenues and influence. Consequently, the president and his entourage stepped up efforts to break into the quasi-autonomous power complex of the Grand Nord. An important way to accomplish this was to weaken Mbusa's position in the national political arena, which would increase his dependency on presidential patronage. When these efforts failed to have the desired effects, the presidential patronage network engineered and co-opted a competitor to divide the Grand Nord power complex.

Mbusa responded to his growing marginalization by employing the same tried-andtested strategies as he had relied on during the war, which had prompted him at the time to maintain links with various armed actors, including Mai-Mai groups, the Ugandan rebels of the ADF, and figures in the Ugandan military establishment. In the post-settlement era, some of these links continued, although not in so overt a fashion or always with the purpose of direct manipulation. Rather, these contacts served as a way of hedging, of continuing to be of relevance to various regimes and factions eager to ward off potential threats, and allowed him to enlarge his room for maneuver by keeping a potential for armed mobilization and side-switching. In so far as maintaining these contacts and pursuing these strategies have contributed to the eastern Congo's ongoing militarization, the fostering of organized violence can be seen as the main security outcome of Mbusa's post-settlement political participation, although this outcome has often been achieved in a more indirect than a direct manner.

The reasons for Mbusa's continuing to covertly play the rebel card lie both within his individual agency, being heir to a form of militarized political strategizing that had been pioneered by his brother Enoch Muvingi, and the nature of the Congo's postsettlement political order. This order contains incentive structures that promote employing armed posturing as a way of political positioning (Stearns et al. 2013). The periodic organization of elections further feeds into this. Not only do elections widen the space for political competition, drawing in large numbers of actors and thereby intensifying competition, they also raise the stakes, due to the zero-sum game nature of the political environment. Furthermore, elections fuel ethnic outbidding, which may lead to the increased mobilization of armed groups formed along ethnic lines. The politico-military entrepreneurs that populate the eastern Congo's political landscape combine electoral politics with various forms of military manipulation, as evidenced by the large number of provincial and national MPs and candidates who 
harness armed groups to influence electoral processes or compensate for their disappointing outcomes (UNSC 2011). In comparison to the pre-war order, these politico-military entrepreneurs have become more numerous, more independent of the political center, and more active also at lower levels of the power pyramid. As such, the post-settlement order seems to be characterized by a type of "democratization" of the strategy of the pompier-pyromane, with politico-military entrepreneurs proliferating at all levels of the system. This democratization unleashes a dynamic that often acquires a momentum of its own, due to the multiplicity of the involved factions and their complex and ever-changing alliances. As a result, not everyone who divides is still able to rule, and not everyone who ignites is still able to extinguish.

Yet, as the political trajectory of Mbusa Nyamwisi and the RCD/K-ML shows, it is not only electoral participation and outcomes that create incentives for political positioning via real or suspected recourse to arms. It was to a large extent Mbusa's efforts to maintain or regain a position in the presidential patronage network that pushed him to continue links with armed actors. Therefore, when analyzing the causes of the militarization of the current order, it is difficult to disaggregate the specific effects of politico-military entrepreneurs' electoral participation from those related to their general inclusion in the political arena, including their integration in the state apparatus and presidential patronage network. At the same time, Mbusa's trajectory illustrates that there are clear limitations to translating control over militarized networks into political capital. Importantly, his power has been increasingly undermined by the rising fortunes of Julien Paluku, who has only limited influence over armed actors. However, even Paluku has benefited from armed mobilization, although in a very indirect manner, trying to capitalize upon the massacres that took place in the course of 2014 and 2015 by engaging in scapegoat politics.

The tragic episode of the massacres demonstrates how, due to the multitude of armed factions that are present in the Grand Nord, as in the eastern Congo as a whole, participation in pompier-pyromania is widening, even though sometimes primarily through smokescreen tactics. By generating profound confusion and uncertainty over perpetrators and alliances, this opaque multitude allows political actors of all stripes to accuse their opponents of engaging in manipulation and violence, regardless of the evidence. These complexities highlight that while the Congo's post-settlement order is militarized, this militarization has become of an increasingly diffuse nature, with covert and suspected alliances with armed groups being as important as the direct and open sponsoring of violence. However, real violence continues to be the engine of this economy of rumors and posturing, and capitalizing upon suspected links to armed groups is only possible when these groups actually exist.

While the described militarization of the post-settlement order is to a large extent an outcome of the wars and the subsequent transition, it draws on developments that started in the pre-war period. At the start of the 1990s, Mbusa's brother Enoch Muvingi pioneered liaising with armed groups as a political strategy. These continuities show how strongly the Congo's post-settlement order is shaped by institutional configurations that developed in the Mobutu era, putting the effects of politico-military entrepreneurs' post-settlement political participation in that order into perspective. Hence, the roots of the current system of pompier-pyromanocracy run much deeper than the post-settlement period, although the dynamics in this period, as shaped by the practices of politico-military entrepreneurs like Antipas 
Mbusa Nyamwisi, have played an important role in its further expansion and democratization.

The fragmentation, volatility and opacity of the political-military landscape fostered by the rise of pompier-pyromanocracy have become increasingly difficult to manage, for the political center and external actors alike. Failing to get a grip on the complex political dynamics, the latter have largely resorted to either purely military or technocratic interventions. Meanwhile, pompier-pyromanes, especially those that are not dressed in fatigues but don the cloaks of respectable politicians, have been able to light their fires quite openly. In fact, despite the reigning confusion, there are often substantial indications which politico-military entrepreneurs are involved in what blaze. Yet the Congolese government has mostly attempted to make use of such allegations for its own benefit, such as by discrediting political opponents.

International actors, for their part, have been hesitant to get involved in the messy and risky business of addressing "rebels in suits" (Verweijen 2013). However, while indeed entailing a risk of being burnt, getting to the source of the fire seems the only viable way for the eastern Congo to rise out of its smoldering ashes.

\section{Notes}

1 Open lists imply that voters can choose any candidate from the political party lists they vote for. A multimember constituency means that each constituency has more than one elected representative, which tends to entrench fragmentation in divided systems.

2 The Banyarwanda encompass a range of groups with different historical trajectories, including communities present on the soil of the Congo Free State when its boundaries were fixed; colonialera labor migrants from Rwanda; and waves of Rwandan refugees arriving on the eve of and at various stages after the Congo's independence (Mamdani 1998).

3 Interview with former RCD/K-ML cadre, Goma, 5 April 2014.

4 Interview with former secretary-general RCD/K-ML, Goma, 6 April 2014.

5 I am indebted to Mehdi Belaid for this qualification of Mbusa Nyamwisi's strategies.

6 Interview with former secretary-general, RCD/K-ML, Goma, 6 April 2014.

7 Interview with RCD/K-ML party cadres, Goma, 6 and 7 April 2014.

8 Information obtained from multiple sources during field research in Beni territory, April 2010.

9 Granting Beni and Butembo the statute of city concerns a war-era policy decision of the RCD/K-ML that was formalized during the transition. Interviews with civil society members, Butembo, 28 April 2010 .

10 Interview with RCD/K-ML party cadres, Goma, 6/7 April 2014.

11 Interview with RCD/K-ML party cadres, Goma, 7 April 2014.

12 “Julien Paluku Kahongya", https://fr.wikipedia.org/wiki/Julien_Paluku_Kahongya

13 Interview with former RCD/K-ML cadre, Goma, 6 April 2014.

14 Information obtained during field research in Beni territory, April 2010.

15 Interview with political analyst, Goma, 7 April 2014.

16 I am grateful to Rachel Sweet for bringing up this point. Personal communication, 12 December 2014.

17 It concerned the ministers José Endundo and Olivier Kamitatu as well as the MP Modeste Bahati Lukwebo.

18 Interview with political cadres RCD/K-ML, Goma, 6 and 7 April 2014.

19 Ibid.

20 With the presidential elections, Mbusa came in fourth at the level of North Kivu with $12.74 \%$ of the votes. In three districts of the Grand Nord, he was the most voted-for presidential candidate: Beni $(36.93 \%)$, Beni ville (32.98\%) and Butembo (44.73\%). Résultats présidentielle par territoires et villes [Results of the presidential elections per territory and per city], http://www.congoforum.be/upldocs/res_pres_territoires_villes_2011.pdf

21 Personal communication with Rachel Sweet, 12 December 2014.

22 Interview with sub-federal president RCD/K-ML, Goma, 5 April 2014.

23 Interviews with journalists working in the Grand Nord, Goma, 6 April 2014. 
24 See for example the list of M23 officers exempted from reintegration into the FARDC published by the DRC government (Radio Kivu 1 Goma 2013).

25 Interviews with ex-Mai Mai Vurundo officers, Butembo, 27 April 2010.

26 Interview with RCD/K-ML cadres, Goma, 6 April 2014.

\section{Bibliography}

Bayart, J-F. 2006 [1989]. L'Etat en Afrique: La Politique du Ventre. Paris: Fayard, 2nd edition (The State in Africa. The Politics of the Belly).

Belaid, M. 2015. "Après la Forêt." Guérilla et Politiques de Sortie de Guerre. Les Combattants Maï-Maï, l'Etat et la Reproduction de la Violence en République Démocratique $d u$ Congo. PhD. Diss, Université Paris 1 Pantheon, Sorbonne. ("After the Forest". Guerilla and Peacebuilding Politics. Mai-Mai Combatants, the State and the Reproduction of Violence in the Democratic Republic of the Congo)

Brock, S. 2009. DRC: Mbusa Nyamwisi -- Yesterday's Man? US Embassy in Kinshasa, 19 June, 09KINSHASA578. Available from http://cables.mrkva.eu/cable.php?id=213003.

Carter Center, 2007. International Election Observation Mission to Democratic Republic of Congo 2006. Presidential and Legislative Elections Final Report, Atlanta, GA.

Carter Center, 2011. Presidential and Legislative Elections in the Democratic Republic of the Congo. Final Report, Atlanta, GA.

CENI. 2012. Elections de Députés Nationaux de 2011.Commission Electorale Nationale Indépendante - Republique Democratique de Congo. Available from http://www.ceni.gouv.cd/deputes/ETAT Depute2011BParListe.PDF.

(The 2011 Elections of National Members of Parliament)

Dibwe dia Mwembu, D. "L'épuration ethnique au Katanga et l'éthique du redressement des torts du passé." Canadian Journal of African Studies/La Revue canadienne des études africaines 33/2-3 (1999): 483-499 (Ethnic cleansing in Katanga and the ethics of redressing the wrongs of the past)

Dougherty. 2006. FARDC Building Up Force Levels in North Kivu. US embassy in Kinshasa, cable 06KINSHASA1870_a, 18 December. Available from https://www.wikileaks.org/plusd/cables/06KINSHASA1870 a.html.

Eriksson Baaz, M. and J. Verweijen. 2013. "The Volatility of a Half-Cooked Bouillabaisse. Rebel-Military Integration and Conflict Dynamics in Eastern DRC." African Affairs 112 (449): 563-582.

Forum des As. 2014. "Le RCD/K-ML désavoue Mbusa Nyamwisi." DigitalCongo, 14 November. Available from http://www.digitalcongo.net/article/103837. (The RCD/K-ML repudiates Mbusa Nyamwisi)

International Crisis Group. 2000. Scramble for the Congo. Anatomy of an Ugly War. Brussels: International Crisis Group.

International Crisis Group. 2003. The Kivus: The Forgotten Crucible of the Congo Conflict. Brussels: International Crisis Group. 
International Crisis Group. 2006. Security Sector Reform in the Congo. Brussels: International Crisis Group.

International Crisis Group. 2007. Congo: Bringing Peace to North Kivu. Brussels: International Crisis Group.

Jokanko. "Pourquoi Joseph Bangakya a quitté Mbusa Nyamwisi?" Le Millénaire (no date). Available from http://lemillenaireinfoplus.e-monsite.com/pages/politique/pourquoi-josephbangakya-a-quitte-mbusa-nyamwisi.html (Why Joseph Bangakay has left Mbusa Nyamwisi?)

Ngoy-Kangoy, K. H. 2007. "The Political Role of the Ethnic Factor around Elections in the Democratic Republic of the Congo." African Journal on Conflict Resolution 7

(2): 219-238.

Ngoy-Kangoy, K. H. 2006. Parties and Political Transition in the Democratic

Republic of the Congo. EISA Research report No. 20. Johannesburg: EISA (Electoral Institute for Sustainable Democracy in Africa).

Lanotte, O. 2003. République Démocratique du Congo.Guerres sans Frontières. De JosephDésiré Mobutu à Joseph Kabila. Brussels: GRIP and Editions Complexe. (Democratic Republic of the Congo. War without Borders. From Joseph-Désiré Mobutu to Joseph Kabila)

La Prosperité. 2010. "Fini la blague à l'AMP. Kabila menace de frapper Kamitatu et consorts!" La Prosperité, 27 May. Available from http://laprosperiteonline.net/show.php?id=4526\&rubrique=La\%20Une.

(Over with the joke to the AMP. Kabila threatens to strike Kamitatu and company)

Le Potentiel. 2010. "Reconfiguration de l'Amp: Un nouveau regroupement politique dénommé 'Centre Libéral et Patriotique' voit le jour." Le Potentiel Available from http://www.digitalcongo.net/article/67207 (Reconfiguration of the AMP. Creation of a new political group named 'Liberal and Patriotic Center' )

Mararo, B. S. 2003. "Le Nord-Kivu au Cœur de la Crise Congolaise." In L'Afrique des Grands Lacs, Annuaire 2001-2002, ed. S. Marysse and F. Reyntjens. Paris: Karthala. (North Kivu at the Heart of the Congolese Crisis)

Mararo, B. S. 2005. "Kinshasa et le Kivu depuis 1987: Une Histoire Ambigue. " In L'Afrique des Grands Lacs, Annuaire 2004-2005, ed. S. Marysse and F. Reyntjens. Paris: L'Harmattan. (Kinshasa and Kivu since 1987: An Ambiguous History)

Mamdani, M. 1998. Understanding the Crisis in Kivu: Report of the CODESRIA Mission to the Democratic Republic of Congo September, 1997. Centre for African Studies, Cape Town.

Matti, S. 2010. "The Democratic Republic of the Congo? Corruption, Patronage, and Competitive Authoritarianism in the DRC. "Africa Today 56 (4): 42-61.

Meece, R. 2006a. FARDC in Eastern DRC Often Undermining Security. US embassy in Kinshasa, cable 06KINSHASA859 a, 31 May 2006. Available from https://www.wikileaks.org/plusd/cables/06KINSHASA859 a.html

Meece, R. 2006b. Presidential Hopeful Nyamwisi Throws Votes To Kabila. US Embassy in Kinshasa, 25 July 2006, 06KINSHASA1179. Available from http://www.cablegatesearch.net/cable.php?id=06KINSHASA1179 
Mwanawavene, R. K., N. B. Bahete and C. N. Bilali. 2006. Trafic d'Armes. Enquete du Terrain au Kivu (RDC). Brussels: GRIP. (Arms Traffic. Field Enquiry in Kivu (DRC))

Nkole, J. K. (no date). "M23 et Mbusa Nyamwisi : la crainte de la répétition de l'histoire?" Le Millénaire, no date. Available from http://lemillenaireinfoplus.e-monsite.com/pages/estde-la-rdc/m23-et-mbusa-nyamwisi-la-crainte-de-la-repetition-de-l-histoire.html (M23 and Mbusa Nyamwisi: fear for a repetition of history?)

Omasomba, J. et al. 2009. Biographies des Acteurs de la Troisième République. Tervuren: Musée Royal de l'Afrique Centrale. (Biographies of Key Figures of the Third Republic).

Radio Kivu 1 Goma. 2013. "Liste complète de commandants du M23 non eligibles a l'intégration dans les FARDC." Radio Kivu 1 Goma, 27 September. Available from http://bukavuonline.com/2013/09/liste-complete-commandants-du-eligibles-lintegration-lesfardc/\#sthash.06JxEwkE.dpuf (Complete list of M23 commanders non-eligible for integration into the FARDC)

Raeymaekers, T. 2004. "The Political Economy of Beni-Lubero.” In Conflict and Social Transformation in Eastern DR Congo, ed. K. Vlassenroot and T. Raeymaekers. Ghent: Academia Press Scientific Publishers.

Raeymaekers, T. 2007. The Power of Protection. Governance and Transborder Trade on the Congo-Ugandan Frontier. PhD Diss, Ghent University.

Raeymaekers, T. 2009. "The Silent Encroachment of the Frontier: A Politics of Transborder Trade in the Semliki Valley (Congo-Uganda)." Political Geography 28 (1): 55-65.

Résultats présidentielle par territoires et villes, http://www.congoforum.be/upldocs/res_pres territoires_villes_2011.pdf (Results of the presidential elections per territory and per city)

Rolley, S. 2014. “ADF-Nalu: Un ancien ministre Congolais met en cause un haut gradé." Radio France Internationale, 25 October. Available from http://www.rfi.fr/afrique/20141025-adf-nalu-ancien-ministre-congolais-met-cause-haut-grade/ (ADF-NALU: A former minister of the Congo warns against a superior officer)

Stearns, J. 2011. Dancing in the Glory of Monsters: the Collapse of the Congo and the Great War of Africa. New York: PublicAffairs.

Stearns, J. Verweijen, J. and M. Eriksson Baaz. 2013. The National Army and Armed Groups in the Eastern Congo. Untangling the Gordian Knot of Insecurity. London: Rift Valley Institute.

Stearns, J. 2013a. From CNDP to M23. The Evolution of an Armed Movement in Eastern Congo. London: Rift Valley Institute.

Stearns, J. 2013b. PARECO. Land, Local Strongmen and the Roots of Militia Politics in North Kivu. London: Rift Valley Institute.

Sweet, R. 2015. "Guest Blog: Politics and Business Intersect in String of North Kivu Killings." Congo Siasa, 6 January. Available from http://congosiasa.blogspot.be/2015/01/guest-blog-politics-and-business.html 
Titeca, K. and K. Vlassenroot. 2012. "Rebels without Borders in the Rwenzori Borderland? A Biography of the Allied Democratic Forces." Journal of Eastern African Studies 6 (1): 154-176.

UNSC. 2002. Final Report of the Panel of Experts on the Illegal Exploitation of Natural Resources and Other Forms of Wealth of the Democratic Republic of the Congo. S/2002/1146. New York: United Nations Security Council.

UNSC. 2011. Final Report of the Group of Experts on the Democratic Republic of the Congo, S/2011/738. New York: United Nations Security Council.

UNSC. 2012. Final Report of the Group of Experts on the Democratic Republic of Congo, S/2012/843. New York: United Nations Security Council.

UNSC. 2013. Mid-term Report of the UN Group of Experts on the DRC S/2013/433. New York: United Nations Security Council.

UNSC, 2016. Final Report of the Group of Experts on the Democratic Republic of the Congo, $S / 2016 / 466$. New York: United Nations Security Council.

Verweijen, J. 2013. "Rebels in Suits. Tackling Civilian Support networks of Armed Groups in the Eastern DR Congo", Amani Itakuya \#8, Christophvogel.net. Available from http://christophvogel.net/2013/10/31/amani-itakuya-rebels-in-suits-tackling-civilian-supportnetworks-of-armed-groups-in-the-eastern-dr-congo/.

Verweijen, J. 2014. "Half-Brewed: the Lukewarm Results of Creating an Integrated Congolese Military." In New Armies from Old. Merging Competing Military Forces after Civil Wars, ed. R. Licklider. Washington DC: Georgetown University Press.

De Villers, G. and J. Omasombo. 2002. “An Intransitive Transition. "Review of African Political Economy 29 (93/94): 399-410.

Vlassenroot, K. and T. Raeymaekers. 2008. "New Political Order in the DR Congo? The Transformation of Regulation." Afrika Focus 21 (2): 39-52.

Willame, J.-C. 2007. Les “Faiseurs de Paix"au Congo. Gestion d'une Crise Internationale dans un État sous Tutelle. Brussels: GRIP and Éditions Complexe. ("Peacebuilders" in the Congo. Management of an International Crisis in a State under Tutelage) 